\title{
Perception of hotel industry partner towards the vocational high school students' internship performance
}

\author{
Samsiwihati*, Bambang Nur Achsan, Budi Santoso \\ Master Program of Vocational Teacher Education, Universitas Ahmad Dahlan, J1. \\ Pramuka, Yogyakarta, Indonesia \\ *Corresponding e-mail: samsiwi_hati@yahoo.com
}

\begin{abstract}
This research is motivated by the fact that there are still many graduates of the hotel expertise vocational school who have not been employed in the hotel industry because the competencies possessed by the graduates are not in line with the market needs. This study aims to: (1) describe the students' performance in the internship program of SMKN 1 Sewon; (2) analyze perceptions of the partner hotel industry on the internship performance of SMK 1 Sewon Bantul students. This research method used a qualitative descriptive approach. The research subjects consisted of seven hotel industries in Yogyakarta. The data sources used primary and secondary sources. Primary data sources were obtained from interviews. Secondary sources were obtained from literature, observation, and documentation. The sampling technique used purposive sampling. The data validity used triangulation, and the data analysis used a qualitative approach by Milles and Huberman. The results of the study concluded that: (1) the performance of internship in the hotel expertise program of SMKN 1 Sewon Bantul was in the excellent category; (2) The perception of the hotel industry partners on the internship performance of SMKN 1 Sewon Bantul students was very good. It was shown by the summary of the results obtained by the assessment in the category of very good with an average of $96.00 \%$. It means that the hotel managers perceive the performance of intern students are categorized as very good and good starting from appearance, speech, mastery of competence, attendance, completing tasks, obeying an order, communication, using tools or facilities, and completing tasks according to procedures and on time.
\end{abstract}

Keywords: hotel industry, internship, internship performance

How to cite: Samsiwihati, Achsan, B. N., \& Santoso, B. (2021). Perception of hotel industry partner towards the vocational high school students' internship performance. International Journal on Education Insight, 2(1), 11-22. DOI: http://dx.doi.org/ijei.v2i1.3956

\section{INTRODUCTION}

Vocational High School (SMK) is a formal education which organizes vocational education in secondary education level (MOEC, 2013). Vocational education is the one provided the need of the industrial world (Hamidah, 2014). The direction and orientation of vocational education is that learners have the ability and capital basic that can support independent living in their environment (Dinyati, 2015). SMK is established to anticipate the needs of a qualified workforce and meet industry competency standards (Mulyadi, 2016), prepare students to enter the workforce, develop a professional attitude, and improve skills or special skills as needed employment (Arga, 2015). So that the direction, orientation, and these objectives can be achieved, then the need to open various vocational skills programs. 
One of the program skills at SMK is the Hotel and Tourism Services. Hotel is included in the service industry that offers room service, food and beverage providers and other services for the general public that are managed commercially (Wiyasha, 2007). The hotel industry and some other related business areas such as travel agencies, restaurants, transportation, and so often also included in the broad group of the hotel industry (Suwithi, 2013).

The hotel industry has a role as one of the main supporting facilities that support the business in the field of tourism. The main function of the hotel business is to provide services to guests in the form of residence or place of stay is temporary. The hotel business's purpose is to support the development of tourism. In order for the functions and objectives of the hotel business to be achieved, competency and professional workforce is needed in the hotel sector. Herefore, the need to open a vocational school department/program expertise hotel.

The reason the opening of the hotel department at SMK namely: (1) build a core competence of vocational students in the field of hotel; (2) provides a range of knowledge and skills of vocational students in hotel-related to travel and tourism, flights and, cruise excursion, hotels, apartments, restaurants, catering, event organization (meetings, exhibitions, conventions), entertainment (entertainment), public relations, marketing and sales, spa, health and sports club, recreational facilities and various attractions other hotel.

Directions learning of SMK majoring in hotel is to produce graduates of human resources ready to work, intelligent, competitive and comparative advantage and strong character as professional workers (Hamidah, 2014), according to demand jobs are needed so that the students after completion of acceptable work in the world of work (DU) and in the hotel industry world (Arga, 2015).

Hotel expertise competence of vocational students in order later graduates can be accepted in the hotel industry, needs to be developed that combines learning theory and practice are balanced with the orientation on the jobreadiness of graduates. Curriculum in Vocational Education competency hospitality expertise, concentrated on the system of learning expertise (apprenticeship of learning) in specific vocational (specific trades), while the content and teaching materials are oriented to the world of work (school-to-work curricula) that integrates both academic skills, life skills, and work skills (Hamidah, 2014).

Integrating academic skills and work skills for vocational students majoring in the hotel can through the internship program. The internship program is the Dual System Education Program integrated in order to learn practical activities, not just at school, but also in the industrialized world. The internship program is a learning process that synergy between education in schools, families, and communities (Hamidah, 2014).

The internship program at SMK aims to provide experience to students about working in the industry and a provision that the students reliable and able to compete in the world of work that will face after graduation (Mulyadi, 2016); improve practical (applied) owned by the students later in the real working world (Kuntadi, 2017).

The internship program has a very important role because it can be a vehicle to meet the needs of students and contribute to the world of work (DU) and industry (DI) of the development efforts in vocational education (Arga, 2015). Helpful vendors to develop potential, attitude, knowledge, and skills

IJEI, Vol. 2, No. 1, April 2021, 11-22 
needed by students for her life and the life of society in general, as a nation, and contribute to the welfare of mankind (Arga, 2015).

The internship program despite having a role, benefits, and clear objectives, but in reality the vocational competence of hotel expertise in the Special Region Yogyakarta still many who have failed in carrying out internships from the planning, implementation, evaluation, and follow-up.

This is supported by the results of research (Kananto, 2015) which states that: (1) planning technical-vocational students majoring in the hotel industry in Yogyakarta in the unfavorable category with a percentage of $39.4 \%$; (2) the implementation of work practices of vocational students majoring in the hotel industry in Yogyakarta in the unfavorable category with a percentage of $35.2 \%$; (3) supervisory practice hotel industry vocational students majoring in Yogyakarta in the unfavorable category with a percentage of $39.4 \%$.

Factors causing the working practices of vocational students majoring hotel industry not good, according to Dinyati (2015) is caused, among other things: lack of infrastructure, poor management, and organization of internships who have not been effective and efficient. Slamet (2013) points out the causes of the failure, among others: (1) students are less serious in carrying out internships in the world of business and industry; (2) the school has not been optimal in organizing internships from the planning, implementation, evaluation, reporting, and follow-up. Syahroni (2014) argues that the phenomenon of failure in carrying out internship in SMK caused by (1) the placement of students who do not conform to their expertise; (2) there are still students who have not able to complete tasks related to their expertise; (3) there are still many students who are unemployed and do not have a job after Completion industry practice; (4) The high number of violations of school rules after students return from the practice of industrial work.

Based on the results of previous studies, shows that the internship implemented by some vocational students in Hotel Skills Competency in Yogyakarta is still not effective. That is still a lot of weaknesses both factors caused by the school/vocational school, students and the hotel is still not optimal. In order for the implementation of PKL running optimally, schools also need feedback from the hotel industry partners regarding the implementation and performance of students during a live the internship program.

Performance assessment is based on the observation rater assessment of the activity of students as occurred. Performance when linked with the performance as a noun (noun), then the notion of performance or performance. Performance is the result of work that can be achieved by a person or group of people in a company in accordance with the authority and responsibility of each in achieving the objectives of the company as illegal, unlawful and contrary to morals and ethics. Assessment is done on the performance, behavior, or the interaction of students. Assessment is done on the performance, behavior, or the interaction of students. The assignment is specifically designed to generate a response (orally or in writing), to produce work (product), or show the application of knowledge. The task given to students must be in accordance with the competence to be achieved and meaningful for students (Sudiyanto, 2011).

The internship program related to performance for students of hotel vocational competency skills are ten aspects are noteworthy indicators, namely: (1) appearance; (2) speech mannered; (3) acquisition of basic knowledge according to its competence; (4) presence; (5) execution of all tasks; (6) to obey the rules/rules in force; (7) communication with DUDI; (8) communication with 
consumers/customers; (9) the ability to use the equipment/facilities in DUDI; (10) execute/complete tasks according to the procedures and timing.

This research is expected to be useful both theoretically and practically. The critically can be utilized for the development of science, especially in the hotel and tourism. The practical benefits of research on the perception of the hotel industry partners for the performance of students the internship program of SMKN 1 Sewon Bantul can be used as an input for information and vocational and hotel managers.

\section{RESEARCH METHOD}

This study uses a descriptive qualitative approach that aims to describe, examine and analyze the performance of the internship program. This study places in the hotel industry in Yogyakarta. The underlying reasons for choosing that location, because SMKN 1 Sewon having Hotel Skills Competency implementing the program of PKL in the hotel industry in the region of Yogyakarta. The subject of research that can assist researchers in disclosing the topics researchers propose is the Hotel Industry in the Yogyakarta area.

Data collection techniques using interviews and documentation. Interviews were conducted to gather information on the management of the hotel industry, the question indicators presented in Table 1.

Table 1. Interview guide

\begin{tabular}{cl}
\hline No & \multicolumn{1}{c}{ Statement } \\
\hline 1 & Participants show appropriate norms of decency. \\
2 & Participants speak manners in accordance with procedures applicable. \\
3 & $\begin{array}{l}\text { Participants master the basic knowledge learned in accordance with the } \\
\text { competence. }\end{array}$ \\
4 & Participants always present on time. \\
5 & Participants can carry out all tasks assigned during the internship well. \\
6 & Participants comply with regulations/rules which apply in DUDI. \\
7 & $\begin{array}{l}\text { Participants can communicate, either with the leadership and staff } \\
\text { DUDI. }\end{array}$ \\
8 & $\begin{array}{l}\text { Participants can communicate better with costumers. } \\
\text { Participants was able to use the equipment/facilities in DUDI } \\
\text { appropriately. }\end{array}$ \\
10 & $\begin{array}{l}\text { Participants can perform/complete tasks according to the procedures } \\
\text { and time specified. }\end{array}$ \\
\hline
\end{tabular}

Documentation is the instrument used to find data on things such as notes, transcripts, books, and others. Documentation used to supplement data from interviews and observations. The instrument used was the recorded document (content analysis). The data collected through the documentation to support or corroborate the data obtained through interviews.

Data were analyzed using the qualitative data analysis model of (Miles $\&$ Huberman, 2014) with stages include data reduction, a data display, and conclusion drawing after data collection. 


\section{RESULTS AND DISCUSSION}

\section{Students' internship performance of hotel program skills}

Based on the results of a study of documentation, interviews, observations, and questionnaires covered about performance PKL student membership program Hotel SMKN 1 Sewon Bantul are presented in Figure 1.

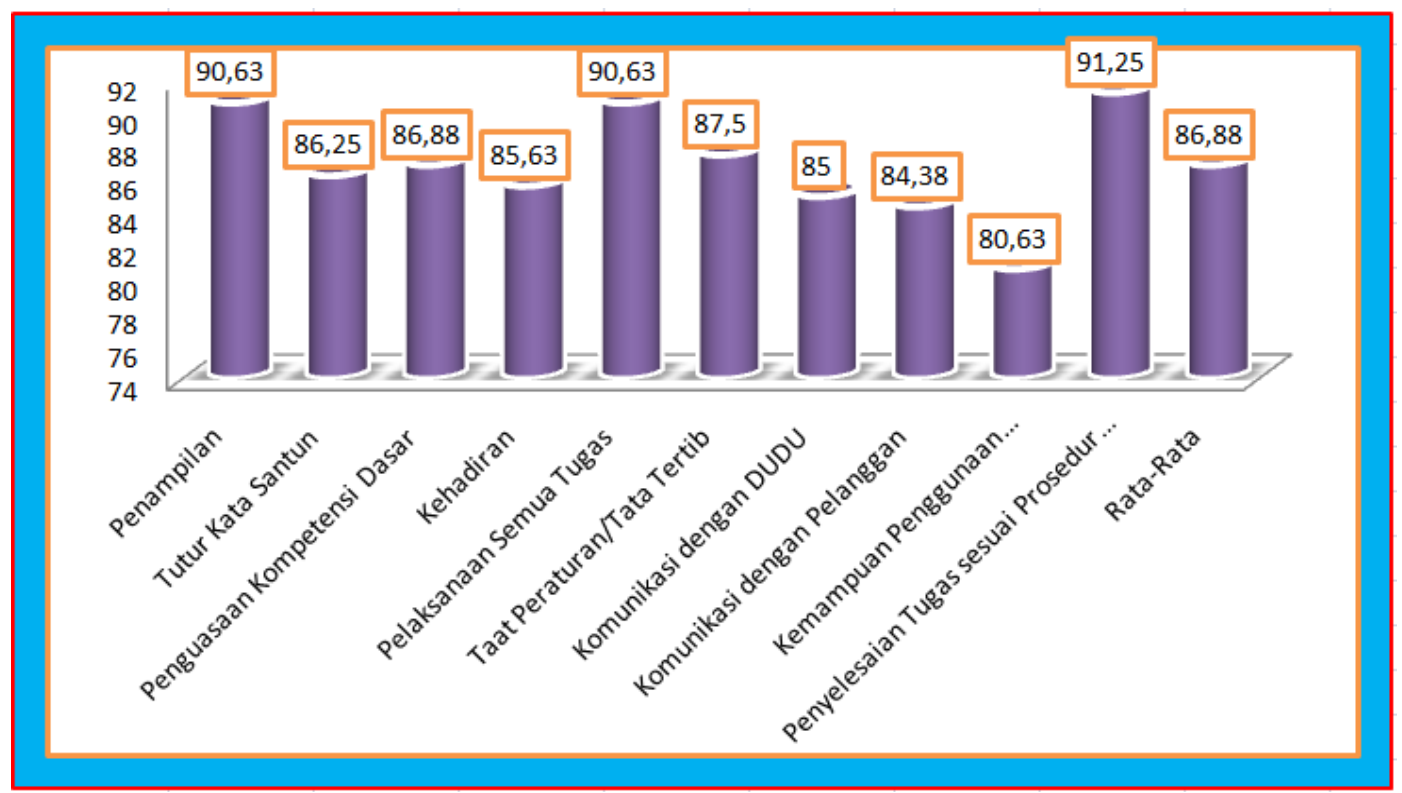

Figure 1. Internship performance of hotel program skills students

Figure 1 describes internship students' performance assessment results hotel expertise competence totaling 32 results average value of 86.88 in the excellent category is in the range (84-100). Very good category to be distributed for performance indicators 90.63 (SB), said words mannered 86.25 (SB), mastery of basic competencies 86.88 (SB) 85.63 attendance (SB), the implementation of all tasks 90.63 (SB ), obey the rules 87.50 (SB), communication with Dudi 85.00 (SB), communication with customers 84.38 (SB), the ability to use facilities DUDI 80.63 (B), the completion of tasks in accordance procedures and timely 91.25 (SB).

Indicators of performance with the highest achievements are the completion of tasks on time with an average score of 91.25 in the excellent category. These indicators need to be developed, maintained and enhanced in the student. The indicator with the lowest achievement is the ability to use the equipment/facilities in DUDI appropriately scored 80.63 in both categories. This indicator needs to be improved and developed in order to increase, due to the ability to use the equipment and facilities is one of the performance requirements that must be possessed by students PKL.

Perception of hotel partners towards students' internship performance

Based on interviews with the managers of the hotel industry Royal Ambarrukmo Hotel, East Parc Hotel, Hotel Melia Purosani Yogyakarta, Grand Dafam Rohan, Horison Ultima Riss Hotel, Grand Tjokro, KJ Hotel, documentation and observation of the perception of the performance of PKL students SMKN 1 Sewon Bantul. The summary of the interviews is presented in Table 2. 
Table 2. Percentage of partner perception on students' internship performance

\begin{tabular}{clc}
\hline No & \multicolumn{1}{c}{ Statement } & \multicolumn{1}{c}{ Percentage } \\
\hline 1 & $\begin{array}{l}\text { Participants show appropriate norms of decency. } \\
2\end{array}$ & $\begin{array}{l}\text { Participants speak manners in accordance with procedures } \\
\text { applicable. }\end{array}$ \\
3 & $\begin{array}{l}\text { Participants master the basic knowledge learned in } \\
\text { accordance with the competence. }\end{array}$ & $85,71 \%$ \\
4 & $\begin{array}{l}\text { Participants always present on time. } \\
5\end{array}$ & $\begin{array}{l}\text { Participants can carry out all tasks assigned during the } \\
\text { internship well. }\end{array}$ \\
6 & $\begin{array}{l}\text { Participants comply with regulations/rules which apply in } \\
\text { DUDI. }\end{array}$ & $100 \%$ \\
7 & $\begin{array}{l}\text { Participants can communicate, either with the leadership and } \\
\text { staff DUDI. }\end{array}$ & $100 \%$ \\
8 & $\begin{array}{l}\text { Participants can communicate better with costumers. } \\
9\end{array}$ & $\begin{array}{l}\text { Participants was able to use the equipment/facilities in DUDI } \\
\text { appropriately. }\end{array}$ \\
10 & $\begin{array}{l}\text { Participants can perform/complete tasks according to the } \\
\text { procedures and time specified. }\end{array}$ & $100 \%$ \\
\hline
\end{tabular}

First, participants dress are in accordance with the applicable norms of decency. Ratings of hotels obtained the percentage of $100 \%$ which includes physical and mental performance. This is in line with the opinions (Suwithi, 2008) which states the appearance of a hotel clerk was the performance in terms of physical and mental accountable embodiment, nice to guests, boss, or coworkers and respectful manner is always ready to carry out their duties with full hotel and a sense of responsibility. Maintain cleanliness and tidiness from head to toe is something that must be implemented. Things to note are as follows: (1) Look neat and clean and polite; (2) Short hair above the collar; (3) For women when long hair should be tied/bun; (4) Do not wear excessive accessory; (5) Do not use excessive make-up; (6) Not a mustache/beard for men; (7) Cleanliness hands, legs, body odorless, long nails are not permitted, (8) Dental hygiene. The illustration is presented in Figure 2.
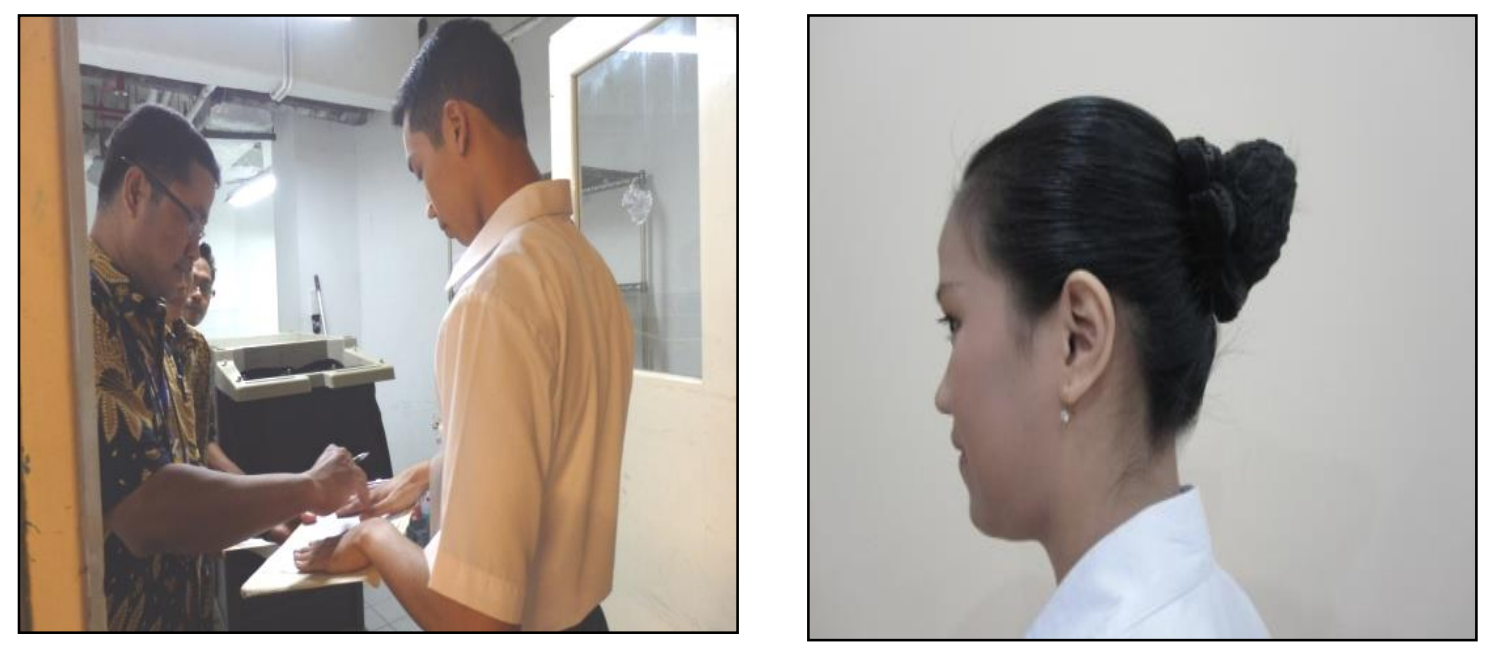

Figure 2. Appearance of internship students 
Second, participants speak manners in accordance with procedures in force. Assessment of the hotel obtained a percentage of $100 \%$, can be described all participants PKL in-spoken manners performed on hotel residence in accordance with the procedure applicable. The oracle was polite and pleasant, good communication, the sincere initiative to do good to the people of the hotel, looking for opportunities to be helpful, the friendly effect has been made by the PKL student, all of which are important elements in doing services at the hotel. (Baatafi, 2006) states: (1) courtesy is an important factor in providing services; (2) treat guests and co-workers well and help with pleasure and sincere because everybody loves to be treated as such; (3) provide satisfaction and comfort to guests.

Third, participants master the basic knowledge of PKL in accordance with competencies learned. Ratings of hotels obtained a percentage of $87.71 \%$, which can be described as not all participants master the basic knowledge of PKL in accordance competencies learned. This is possible due to the synchronization syllabus of PKL who implemented yet include all the hotel industry in the region of Yogyakarta so that there are gaps in science and technology development in the SMK in the industry. Kuntadi (2017) mention the cause of disharmony education in vocational needs DUDI as follows: (1) The ability of some of the teachers at the school in the hard skills and soft skills does not meet industry standards; (2) Learning some competence is still a traditional simulation and are not yet using the working world standards; (3) Lack of infrastructure, especially the practices of the facility equipment type and amount; (4) Not to do synchronization and validation of the standard curriculum in school with the world of work. This leads to formal education has not been fully provided supplies for graduates to be able to work in accordance with the areas of expertise;(5) There are gaps development of science and technology in vocational with the development of science and technology; (6) The lack of knowledge of learners to the real working world; (7) Many job seekers are not aware of career guidance services; (8) The lack of planting efforts entrepreneurship for learners; (9) Low soft skills most learners in particular vocational motivation, communication, self-reliance, hard work and confidence that the cause can not and ordinary face the challenges that exist in the world of work. To solve these problems the school invited all of the hotel industry in the province to synchronize the syllabus of internships, bring industry practitioners to teach and improve the competence of teachers so that students become competent and ready to enter the world of work.

Fourth, all participants always present on time. Assessment of the hotel obtained a percentage of $100 \%$, can be described all participants PKL always come on time in accordance with the work shift that has been given. Shift work is shifting or the determination of working hours (on working hours in general) that occurs once every 24 hours in 3 shifts with the aim of optimizing the work and productivity, each of which consists of 8 hours of work each of her shift. If the hours of work in a company made as much as 3 shifts with each of a maximum of 8 hours per day (including breaks), the accumulative number of hours worked each shift should not be more than 40 hours per week. Employees who work beyond the provision must work with the knowledge of the government and a letter written from the company counts as overtime. In a schedule of the school to submit entirely to the industry concerned.

Fifth, all participants can carry out all the tasks assigned for PKL well. Perception hotel in terms of the percentage of $100 \%$ is obtained. It can be described that PKL participants can carry out the task for 6 months with both

Perception of hotel industry partner towards the vocational high school students Samsiwihati, Achsan, \& Santoso 
the benchmarks students obtain a certificate of internships in the industry.PKL implementation pattern in SMKN 1 Sewon Bantul implemented by a system of blocks with 6 months full pattern in the industry and students are expected to apply the knowledge acquired in school, broaden, enhance competence according to the field and can contribute to the work dunums. This is consistent with the Kuntadi (2017) which states internship benefits for students: (1) Apply and increase the knowledge that has been gained in the school; (2) Adding insight into the world of work, especially in the form of direct work experience (real) in order to instill a positive work climate that is oriented to the quality care process and the work; (3) Increase and enhance the competence and can instill a high work ethic; (4) It has a productive capability in accordance with the competence of the skills learned; (5) Develop ability in accordance with the guidance/direction supervising the industry and can contribute to the world of work.

Sixth, participants obey the rules/rules which apply in DUDI. Rate of hotel gained $100 \%$, it can be described that participants could obey the rules / rules prevailing in the industry. so that no sanctions were accepted, students. The rules mean a set of rules that apply to create orderly conditions (Moenir, 1983). The rules in the hotel are the rules that have been agreed by an institution that must be obeyed by students if breached will be given sanctions, has the nature of force, making it mandatory for students rules that have been agreed upon have sanctions for anyone that violates.

Seventh, participants can communicate both with the leadership and staff DUDI. Assessment of the industry gained 100\%, can be described students are able to communicate effectively with staff and DUDI. Effective communication occurs when something (a message) notified the communicator can be received well or equally by the communicant, so there were no misunderstandings. Effective communication purpose is to provide convenience in understanding the messages conveyed between the giver and the receiver so that the language more clear, complete delivery and feedback balanced, and trained to use nonverbal language as well. It has been carried out on students PKL marked with the message has been conveyed properly, be accepted in accordance with the intended and expected, no misunderstandings, problems can be resolved quickly, the relationship more closely intertwined. Effective communication is characterized by the lack of understanding, can cause pleasure, influence attitudes, improve good social relationships, and ultimately result in any action, as presented in Figure 3.
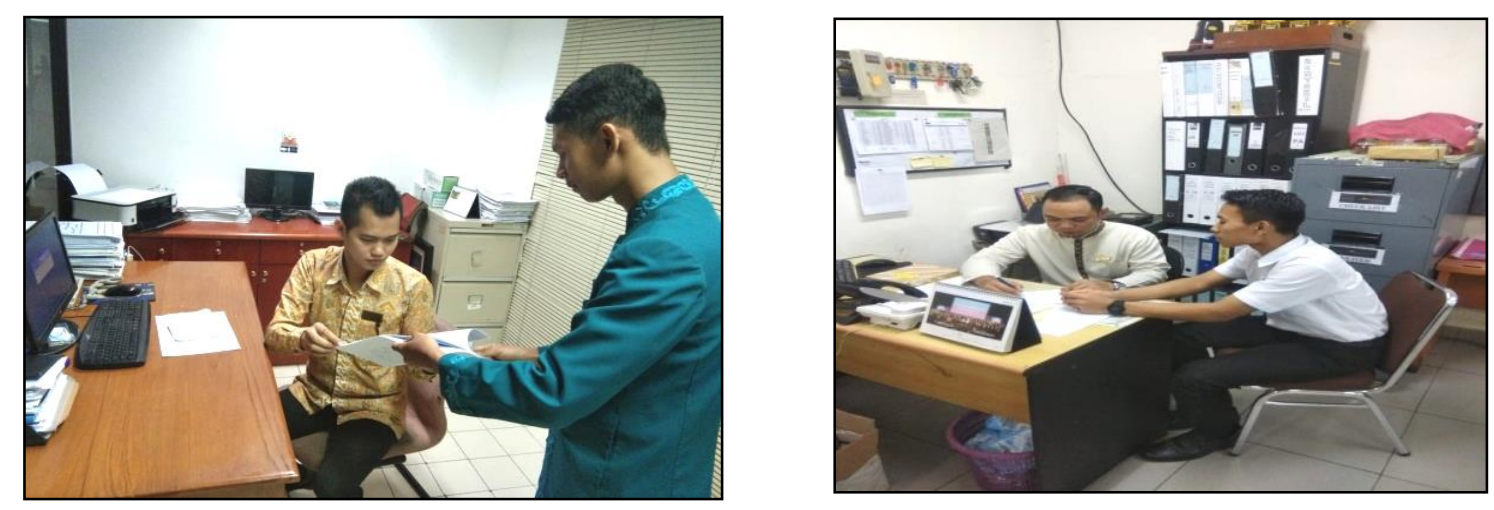

Figure 3. Communication between students and working place 
Eighth, participants can communicate better with consumers / customers. Assessment of industrial values obtained $85.71 \%$, can be described as students who have not been able to communicate effectively with guests/ customers. This is because the student internships still lack confidence in communicating with foreign guests, especially guests who communicate with English as well as students are less interested in learning English. Some testimonies we got from the partners are:

"Students improve English competence" (Prapti Handayani, Horison).

"Communication in English improved" (Renny W., Jambuluwuk Hotel).

"Never be satisfied with what has been achieved" (Eddy S., Grand Dafam).

A solution of the results of these studies adds the ability to speak English school through extra-curricular learning the English language and the productive use of the English language to improve the English language competence of the students and so that students will be more confident. Figure 4 shows the communication skills of the students with foreigner.
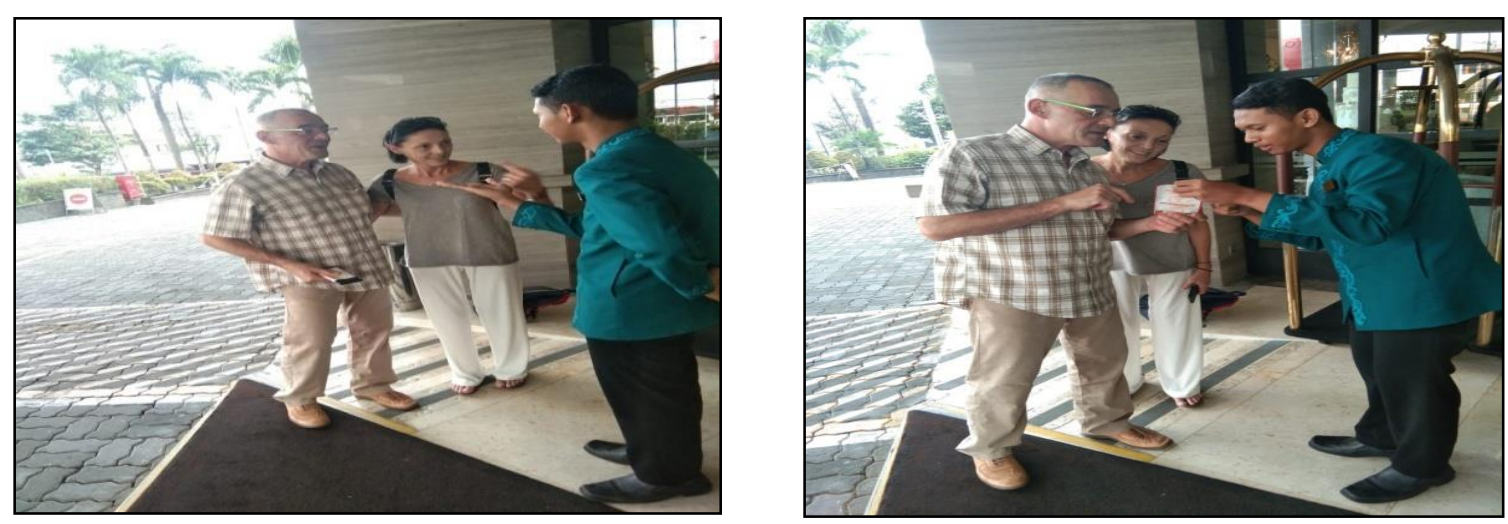

Figure 4. Communication between students and foreign guests

Ninth, participants were able to use the equipment/facilities in DUDI appropriately. Assessment of industrial values obtained $85.71 \%$, can be described that the students have not been able to use the equipment/facilities in DUDI appropriately. This is because the equipment in the school practices not in accordance with the existing equipment in the industry, so the results are less than the maximum. This is in accordance with the opinion of Widyastuti et al (2020) that vocational education will be effective if the environment in which learners are trained is a replica of the environment in which she will work. A solution to the school is soon to hold equipment standard practice in accordance with the industry, so there is no gap.

Tenth, participants completed tasks according to the procedures and time specified. Assessment of the industrial value of $100 \%$ is obtained, it can be described that the student is able to execute/complete tasks according to the procedures and time specified. This is in line with the opinion (Baatafi, 2006: 87) states: Standard Operating Procedure (SOP) is a guide to the procedures for implementing the duties as the standard for general and specific to each position. An SOP is practiced in the hotel for students to carry out include SOP Front Office, SOP Floor, Public Area SOP and SOP Laundry. In carrying out the task in the hotel, students task in accordance with the job description of the 
industry standard with the guidance of a supervisor. Figure 5 and Figure 6 show the examples of the services.
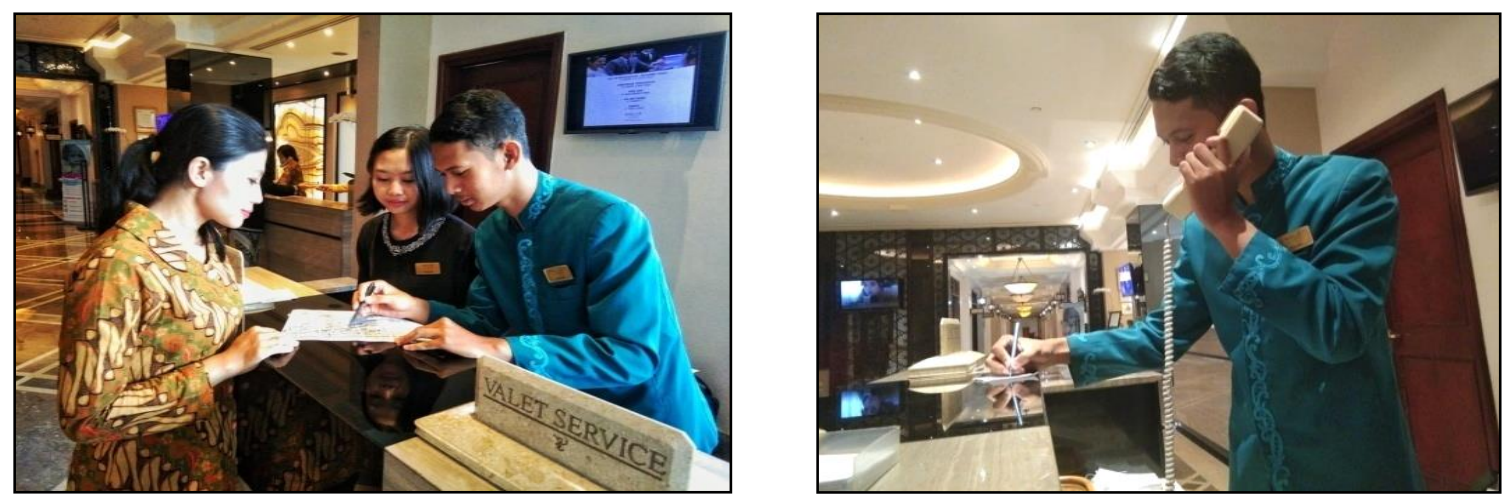

Figure 5. Students valet practice and service operator phone practice
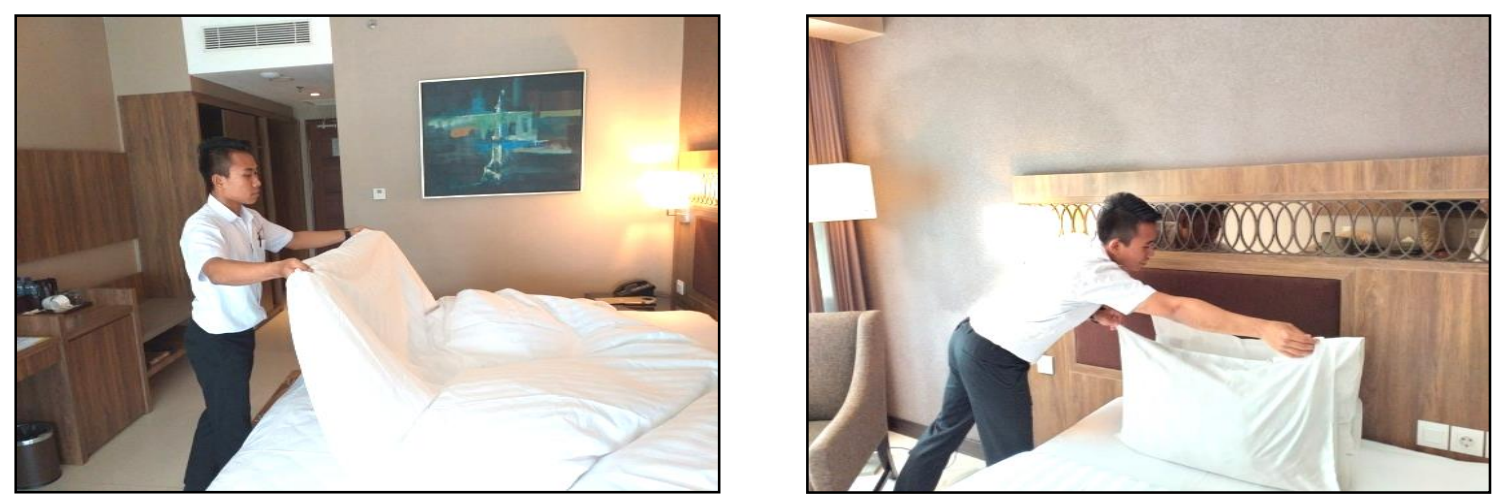

Figure 6. Students practice to make up room

\section{CONCLUSION}

Based on the results of the research and discussion summarized as follows. First, students' internship performance competence hotel expertise SMKN 1 SEWON Bantul in the excellent category. Evident from the results of the assessment of the performance of students gained an average of 86.88. 86.88 This means student performance is very good and well, only $13.12 \%$ of students whose performance in the category of poor and not good so it needs to be improved and enhanced. Second, the perception of the hotel industry partners for the performance of students is very good. Evident from the summary of the interview obtained by judging in the excellent category with an average of $96.00 \%$. That is, the hotel manager perceives the performance of vendors already categorized very well and good, only $4.00 \%$ perceived lack of good and bad. Performance perceived very well and both include: participants PKL dressed in accordance with the norms of decency applicable, have spoken said politely, present on time, served well, obey the rules/order, has been communicating with the leadership and staff DUDI, and complete the task was based on procedures and timing. It's perceived poor and not good include: competence of students, communication with customers, performance in English. This indicator needs to be improved so that internships in the future better. 
School needs to build networks with more hotel industry both in the implementation of internships, the synchronization program syllabus and cooperation in terms of guest teachers from the industry so it will not be a gap between schools with industry. Besides, the school in order to equip students with English skills before internship, so that students are more confident in the ability to talk English when communicating with foreign guests.

\section{REFERENCES}

Arga, P. (2015), Praktik Kerja Lapangan (PKL) Sekolah Menengah Kejuruan, Jakarta: Direktorat Pembinaan Sekolah Menengah Kejuruan, Kementerian Pendidikan dan Kebudayaan.

Baatafi. (2006). Housekeeping Departement Floor \& Public Area. Bandung: Alfabeta.

Dinyati. (2015). Belajar dan Pembelajaran di SMK. Jakarta: Rineka Cipta.

Hamidah, S. (2014). Pengaruh self-efficacy, lingkungan keluarga, dan lingkungan sekolah terhadap minat berwirausaha siswa SMK jasa boga. Jurnal Pendidikan Vokasi UNY, 4(2), 195-207.

Kananto, A. (2015). Efektivitas Pelaksanaan praktek kerja industri Kelas XI di SMK Marsudi Luhur I Yogyakarta. Tesis. Yogyakarta: Universitas Negeri Yogyakarta.

Kuntadi, M. (2017). Pedoman Praktik Kerja Lapangan (PKL). Jakarta: Direktorat Menengah Kejuruan.

MOEC. (2013). Undang-Undang Nomor 20 Tahun 2013. Jakarta: Sekretariat Negara RI.

Miles \& Huberman. (2014). Qualitative Data Analysis (A Methods Sourcebook). Sage Publication.

Moenir, A.S. (1983). Pendekatan Manusiawi dan Organisasi terhadap Pembinaan Kepegawaian. Jakarta: Gunung Agung.

Mulyadi, A. (2016). Efektivitas praktik kerja industri sesuai dengan tuntutan dunia kerja. Tesis. Yogyakarta: Universitas Negeri Yogyakarta.

Slamet. (2013). Pegembangan SMK model untuk masa depan. Jurnal Cakrawala Pendidikan, 22(1), 14-15.

Sudiyanto. (2011). Teaching Factory di SMK ST. Mikael Surakarta. Yogyakarta: Fakultas Teknik Universitas Negeri Yogyakarta.

Suwithi, N.W. (2008). Akomodasi Perhotelan Jilid 2. Jakarta: Direktorat Pembinaan Sekolah Menengah Kejuruan.

Syahroni, F. (2014). Persepsi siswa terhadap manfaat pelaksanaan praktik kerja industri di SMKN 1 Lembah Gumanti. Jurnal Administrasi Pendidikan UNP, 2(1), 275-831.

Widyastuti, E. R., Santosa, B., \& Sayuti, M. (2020). Perception of car workshop partners towards the vocational students' internship performance in Cilacap. International Journal on Education Insight, 1(2), 61-68.

Wiyasha, I. B. M. (2007). Akuntansi Manajemen untuk Hotel dan Restoran. Yogyakarta: Andi Offset. 
This page is intentionally left blank.

IJEI, Vol. 2, No. 1, April 2021, 11-22 